\title{
WHAT IS THE IMPACT OF PRICE FACTORS ON SUSTAINABLE TOURISM COMPETITIVENESS?
}

\author{
Snežana Radukić ${ }^{1}$ (i) \\ Zorana Kostiće ${ }^{2}$
}

DOI: https://doi.org/10.31410/tmt.2019.169

\begin{abstract}
The purpose of this paper is to evaluate the connection between price competitiveness and overall tourism competitiveness of the Balkans and Eastern Europe Countries. By comparing the selected economic variables, a comparative analysis of the price competitiveness in tourism for this group of countries in the period from 2007 to 2018 was carried out. The empirical research was designed to test whether the Balkans and Eastern Europe countries which are more competitive in tourism simultaneously have lower price competitiveness. The hypothesis has been tested by using modern statistical software. The significance of this research arises from the current debate whether the price factors of competitiveness in tourism are sustainable in long run. Taking into account the specificities of the tourism sector in different countries, and combining observations and suggestions, the paper could give significant contribution to understanding the trends, issues and policies in this area.
\end{abstract}

Keywords: Price Competitiveness, Tourism Competitiveness, Sustainable Development, Balkans and Eastern Europe Countries.

\section{INTRODUCTION}

$\mathrm{T}$ ourism is one of the most growing industries and engine of the national economies (Galovski, 2018). In recent decades, tourism has taken on the form of the most massive socioeconomic phenomenon in the world, and has become one of the most dynamic segments of the service sector, whose share in the creation of GDP in the developed market economies has grown steadily. As a propulsive economic activity characterized by a heterogeneous structure, tourism is an important strategic element for the development of many developing countries and regions, and the mechanism for narrowing the growing economic gap between the developed and developing countries (Harrison, 2001; Sharpley \& Telfer, 2008, Mowforth \& Munt, 2009).

Tourism as an economic activity is directly exposed to continuous changes. Most recently, there has been a trend towards increasing the spatial diversification, which has an impact on increasing international tourism flows and improving competitiveness. This trend has also been reflected in the increasing consumption per visitor to the destination. New tourism markets and proactive tourism development policies in the receiving countries will be the primary development drivers (Kester \& Croce, 2011). Economies in which tourism participates with the highest percentage in GDP and whose growth depends on the tourism industry have been forced to strengthen their competitive advantages in conditions of severe competition in the international market. Economies which depend on the tourism industry have chance to make their destinations competitive if they meet the tourists needs (Gooroochurn \& Sugiyarto, 2005).

\footnotetext{
University of Niš, Faculty of Economics, Trg kralja Aleksandra Ujedinitelja No. 11, 18000 Niš, Republic of Serbia

2 Faculty of Sciences and Mathematics, University of Niš, Republic of Serbia, Višegradska No. 33, 18000 Niš, Republic of Serbia
} 
The country's competitiveness as a tourist destination depends on the number of attracted tourists and spent money in the tourist destination country, which contributes to the increase in GDP of the selected country. That's the reason why each country competes to attract as many tourists as possible (Dwyer et al., 2000).

The tourism competitiveness models evolved from the simple models that put an emphasis on proper marketing position as the most important to achieve the destination's competitiveness, up to very complex competitiveness models that respect numerous competitiveness factors, examine their interconnection or deal with the prediction of the competitive position of the destination in future.

Since 2007, the Travel \& Tourism Competitiveness Index (TTCI) of the World Economic Forum becomes a generally accepted indicator for the tourism sector competitiveness at the national level. The main goal of this methodology is to quantify the impact of factors and policies that affect the attractiveness and development of the tourism sector in different countries (WEF, 2017). According to the Reports on the Competitiveness of Tourism and Travel in 2015 and 2017 (WEF, 2015, 2017), the main sub-indices are: 1) Enabling Environment; 2) T \& T Policy and Enabling Conditions; 3) Infrastructure; and 4) Natural and Cultural Resources. In the framework of the T \& T Policy and Enabling Conditions sub index and creation of conditions for its realization, besides giving priority to tourism and travel, and openness to the international market, the third pillar is Price competitiveness. The airport taxes, hotel prices, purchasing parity power, and fuel price level have great importance for higher level of price competitiveness.

The paper is structured as follows. After the introduction and literature review, the third part of papers presents applied research methodology and the underline hypothesis. After that part research results and their discussion are given, followed by concluding findings in the final part of the paper.

\section{LITERATURE REVIEW}

Issues and problems from the domain of improving the tourism competitiveness have recently been the subject of the constant interest of numerous researchers (Ritchie \& Crouch 2003; Enright \& Newton 2004; Crouch 2011; WEF, 2011). According to Petrović et al. (2017), researches dealing with different aspects of tourism or the destinations competitiveness can be divided into those that are aimed at the general models and destination competitiveness theories development, those that are aimed at diagnosing the particular destination competitive position, and those that are focused at certain aspects of the destination competitiveness. Over the years, various studies have used different competitiveness indicators depending on specific tourism factors and general business factors, which included micro and macro environment (Kayar \& Kozak, 2007; Ivanov \& Webster, 2013; Krstic et al., 2016).

The tourism demand determinants have been occupying the attention of numerous theoreticians from various disciplines for long time (Li et al., 2005; Divisekera \& Kulendran, 2006; Song \& Li, 2008). Understanding the tourism demand determinants has great importance for determining the key competitive advantages of each country in order to improve the tourism competitiveness. Tourism demand includes the measurement of using goods and services by visitors (Frechtling, 2001). 
The tourism demand is influenced by a large number of factors. However, most econometric studies mainly focus on economic factors. According to Lipsey (2009) the price is main determinant of demand. Economic theory also suggests that the price of tourism products/services is negatively linked to tourism demand. The price variables should include the prices of the goods and services related to both the destination and substitute destinations. Additionally, marketing expenditure, consumer tastes, consumer expectations, habit persistence, origin population and one-off events are all potentially important factors that could be incorporated into the tourism demand model (Song \& Witt, 2000). In various models of prices in tourism, the formation of flavours and income from the origin country are the most important determinants of international tourism demand (Muchapondwa \& Pimhidzai, 2011). Price factors as the most important tourism demand determinants include the costs of transport services and the costs of ground content (Dwyer et al. 2000, p. 9). The competitiveness of a tourist destination is a concept that includes price differences that correspond to exchange rate movements, the productivity level of various components in the tourism industry and other qualitative factors that affect the attractiveness of the tourist destination (Forsyth \& Dwyer, 2009). Price competitiveness is the main component of the overall competitiveness of the tourist destination. Total tourist costs include transport costs to and from the tourist destination, as well as the amount spent during at a tourist destination, including accommodation, tour packages services, food and beverages, entertainment, etc. The total price determines the tourist's decision for travelling to a particular destination (Dwyer et al., 2000).

Tourist competitiveness is fundamentally linked to the tourist's consumption. Ritchie and Crouch (2003) claim that the tourist destination becomes competitive if there are the opportunities to increase the costs of tourists and attract as many tourists as possible, which will increase the earnings of tourism foreign exchange. However, the low-price level is not a guarantee for higher incomes of a tourist destination. If demand is inelastic to price, then the price reduction strategy will not be able to increase foreign exchange earnings of the destination. Therefore, the approach of price elasticity is used to measure the tourism competitiveness in terms of prices.

In some research the focus was on determining destination price competitiveness. The variations in the tourism destination cost generate important economic impact on destination shares of total travel abroad (Dwyer et al., 2000, p. 9). The analysis of price competitiveness as an important determinant of the tourism sector competitiveness was carried out in the study of Dwyer et al. (2002). However, they did not analyse how price competitiveness affects the spending in a tourist destination.

Several studies that contain research models are the studies of Cortez-Jimenez et al. (2009), Li et al. (2004), and Mangion et al. (2005). These studies have applied the AIDS demand system model for the tourism demand analysis in Europe and the results have shown that foreign tourism demand is price sensitive, but the level of their sensitivity varies depending on the country origin and tourist destination.

In the latest research (Plessis \& Saayman, 2018) on the example of South Africa as a tourist destination, by using a structured questionnaire, it was found that more than half of the respondents consider that price increase has a significant effect on tourism sales. The main price components of the tourism products and services (fuel prices, inflation, exchange rate, electricity cost and labour costs) have the greatest impact on the competitiveness of the destination. 
However, Lim (2006) comes to the conclusion that the price increase of a particular tourist destination turns the decision of potential tourists towards alternative destinations. Such tourists' behaviour can be explained in two ways. First, the substitution of destinations can be determined by specifying the tourists' cost and if the alternative destination is more expensive than the tourist chooses the origin country (Song et al., 2000). Second, the substitution of destinations can be determined by comparing the visiting cost of an alternative destination with weighted average cost of visits in different competing destinations, adjusted by the relevant exchange rates (Song \& Turner 2006).

Measuring the price of goods and services in a destination implies a complex procedure. It is necessary to calculate the tourist price for a package of goods and services used by representative tourist in the destination. In this way, composite prices are constructed in the form of a price coefficient in the destination and price in origin countries (Li et al., 2005). Relative prices converted into local currency are called the tourism price index. Construction of tourism price indices is often complicated by the lack of data on real goods and services consumed by tourists and their prices (Dwyer et al., 2000; Forsyth \& Dwyer, 2009; Dwyer \& Forsyth, 2011). The real exchange rate is presented as an adequate approximation of changes in the relative prices that tourists face. The real exchange rate is most often used to display prices in tourist demand models (Song \& Li, 2008). Studies, such as Halicioglu (2010) and Seo et al. (2009) provide evidence of a strong link between outbound tourism and real exchange rate.

Competitiveness indices were not widely used as price variable in tourism demand analysis, but they are starting to be applied (Athanasopoulos et al., 2014; Etzo et al., 2014). The price competitiveness index (PCI) measures the relative price competitiveness of the destination, uses the World Bank data, and it can monitor the relative price competitiveness of the destination and its change in time, as well as it can assess the price demand elasticity in tourism. The application of PCI for tourism demand modelling can be found in Athanasopoulos et al. (2014) and Etzo et al. (2014). Calculating this index takes into account the relative purchasing power parity (PPP) at the destination.

\section{RESEARCH METHODOLOGY AND HYPOTHESIS}

In this paper, TTCI is applied. This index is based on the theory of economic productivity and consists of three outputs (tourism receipt per arrival, tourism added value ration of GDP, growth rate of tourism receipts), so each show different aspects of industry productivity (Croes, 2010).

The subject of the analysis in this paper is the relationship between price competitiveness, as a pillar of the TTCI, and the overall tourist competitiveness of the EECs (Hungary, Slovenia, Poland, Moldova, Bulgaria, Slovakia, Romania) and WBCs (Serbia, Montenegro, Bosnia and Herzegovina, North Macedonia, Albania). A comparative analysis of the price competitiveness pillar for these two groups of countries was carried out. The classification of countries into selected groups was taken from the World Economic Forum and from the TTCI report for 2017. Empirical research tests the following hypothesis:

Hypothesis 1: The WBCs are more competitive than the EECs.

Hypothesis 2: The EECs will more concentrate their tourism competitiveness towards price factors. 
Considering the structure of TTCI, in particular pillar price competitiveness, one of the main aims of the paper is to determine the impact of the individual components of pillar price competitiveness on its total value. This means that the paper highlights the impact of each price competitiveness pillar component on overall tourism competitiveness, and stands out components that need to be improved in order to increase tourism competitiveness. In addition, the paper estimates the sustainability of the achieved price competitiveness.

In this paper were used methods of statistical analysis. Special attention is on the correlation and regression analysis. With these methods, it is possible to determine the character of connectivity, the significance of the connection and the influence of certain parameters from the TTCI structure on price competitiveness. In addition, the forecasting method, based on the intensity trend of the selected variable, was used.

The information basis of this research related to the World Economic Forum. Methodological explanations were based on the data from the Reports on Competitiveness of Travel and Tourism for the period from 2007 to 2017. One of the limitations during the research is the fact that the methodology of calculating TTCI over the years has changed in terms of considering the various components in the structure of the index, i.e. the pillar.

In this paper was primarily conducted the analyses of the TTCI values for selected group of countries. A special attention is devoted on the values of the pillar price competitiveness and its components for each country. The correlation between pillar price competitiveness and its components was determined separately for two groups of countries. Regression analysis was used in order to examine the influence of the price competitiveness pillar components on its overall value, for both groups of countries. The cluster analysis was carried out in order to classify all countries into homogeneous groups according to the value of the pillar price competitiveness. Finally, the future values of pillar price competitiveness are projected for the two coming periods.

\section{RESEARCH RESULTS AND DISCUSSION}

For research purposes, the data were taken from the Travel and Tourism Competitiveness Reports for 2007, 2008, 2009, 2011, 2013, 2015 and 2017. Depending on the year, the number of covered countries is different, so in 2007, 124 countries were included; 130 countries were analyzed in 2008; 133 countries in 2011; 139 countries in 2011; 140 countries in 2013; 141 countries in 2015, and 136 countries around the world in 2017. Serbia and Montenegro are viewed as one country in the 2007. By applying a comparative analysis, each country is compared with other countries in the analysed period of time.

According to the TTCI ranking within the observed group of countries in 2007, the Slovak Republic, Hungary and Slovenia have the highest values of TTCI. These are, at the same time, high-ranking countries and within the 130 countries discussed in the Travel and Tourism Competitiveness Report for that year. Based on the Report from 2007, Bulgaria occupies a 54th place, followed by Serbia and Montenegro (61st), Poland (63rd) and Romania (76th). North Macedonia (83rd), Albania (90th), Moldova (95th) and Bosnia and Herzegovina (104th) were ranked worst in 2007. The positioning of the observed countries in the next year (2008) is similar to the previous year, but with the TTCI values slightly lower than in 2007. TTCI values range from 4.60 to 3.45 in the group of countries in 2008. Oscillatory movement of TTCI values is also characteristic for 2009 , but half of the observed countries recorded better positions on the 
ranking list due to higher values of the indicator. The declining trend, characterized in 2009, was interrupted in 2011, and higher TTCI values were recorded in all countries. Slovenia (33rd) had the highest-ranking position from the observed group of countries, while Moldova (98th) had the lowest position.

According to the Reports, Serbia has improved position based on TTCI values. There was a decrease in TTCI values for WBCs from 2009 to 2017, which inherently reduces their ranking in the list of all countries. Montenegro has recorded the most significant decrease in the TTCI value from the group of WBCs, which dropped from the 36th position in 2011 to 72rd in 2017. Similarly, the group EECs has also fallen on the world ranking according to the level of tourism competitiveness. Slovenia is still high on the list (41st in 2017). The most pronounced drop in TTCI value, observing the change from 2007 to 2017, was recorded in Slovak Republic (from 4.68 to 3.90), which also affected the change in ranking position (from 37th place in 2007 to 59th place 2017). The minimal change in TTCI values has observed in Poland and Bulgaria, which have been on the same positions throughout the analysed years.

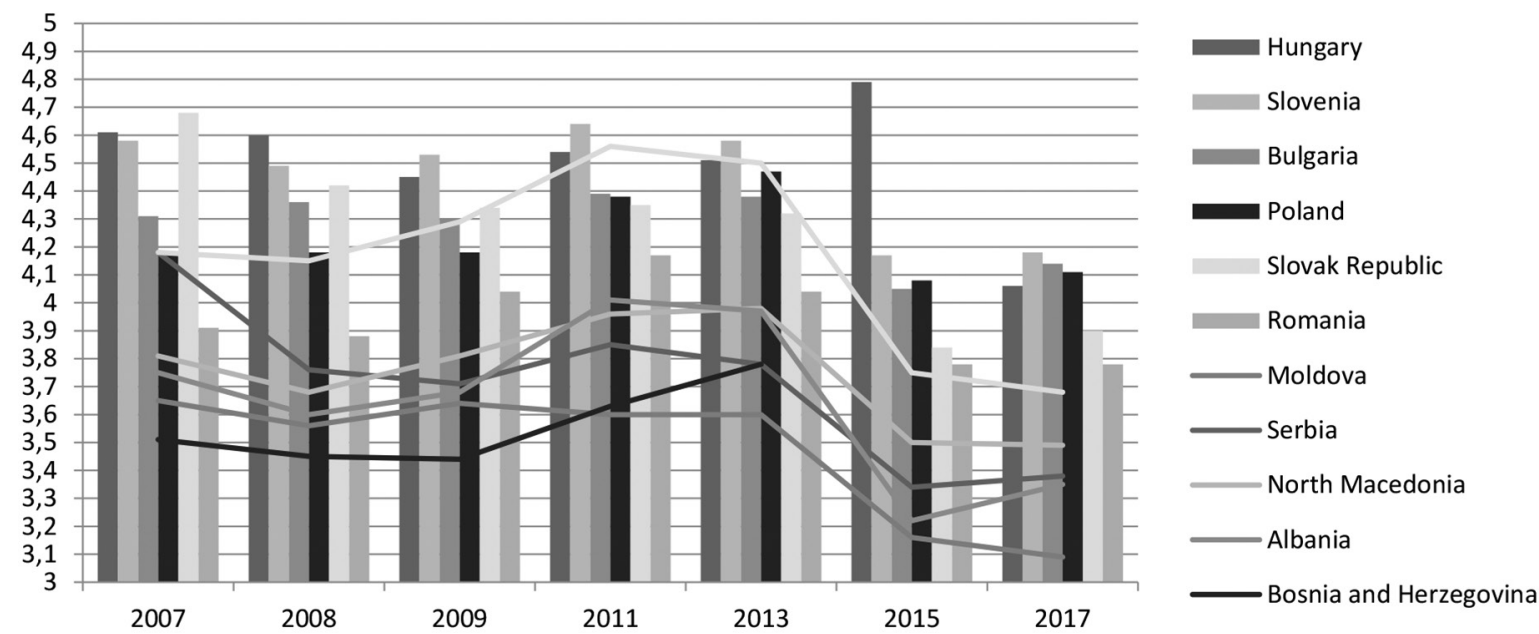

Figure 1. The achieved level of tourism competitiveness in WBCs and EECs according to TTCI (2007-2017)

Source: Authors' presentation based on the data from the WEF's Travel \& Tourism competitiveness Reports.

The aggregate indicator (value of TTCI) does not have a great analytical value, so the deeper analysis focuses on the pillar Price competitiveness. However, the structure of this pillar was not the same throughout all analysed years. In 2007, this pillar consists of the following four components: Ticket taxes and airport charges, Purchasing power parity, Extent and effect of taxation, Fuel price levels, and since 2008 a component Hotel Price Index has been added. The change in methodology regarding the components comes in 2015, when the component Extent and effect of taxation is removed from the structure. The component Ticket taxes and airport charges measure the relative cost of using international air traffic services based on the level of airport taxes, tax on tickets and value added tax. It reflects the costs arising from the using air traffic lines upon arrival and the departure of a large number of passengers at international airports in each country. Purchasing power parity is a factor of conversion of purchasing power parity to the official exchange rate. Extent and effect of taxation show the influence of the level of taxes for stimulating work and investing. A fuel price level is an indicator that shows the price of the best-selling diesel fuel expressed in US cents per litre. Hotel Price Index measures the average 
price, expressed in US dollars, for the first-class accommodation in each country. The index is calculated according to the average rate of overnight stays achieved in first class hotels in each country for the period of 12 months in order to avoid seasonal fluctuations.

Table 1. Price competitiveness pillar's values for the EECs and WBCs (2007-2017)

\begin{tabular}{|l|c|c|c|c|c|c|c|c|}
\hline $\begin{array}{l}\text { Category/ } \\
\text { Country }\end{array}$ & PC2007 & PC2008 & PC2009 & PC2011 & PC2013 & PC2015 & PC2017 & $\begin{array}{c}\text { Change } \\
\mathbf{2 0 0 7}=\mathbf{1 0 0}\end{array}$ \\
\hline Hungary & 4.07 & 4.43 & 3.90 & 4.40 & 4.29 & 4.60 & 4.70 & 115 \\
\hline Slovenia & 3.87 & 4.21 & 4.20 & 4.30 & 4.00 & 4.34 & 4.60 & 119 \\
\hline Bulgaria & 4.63 & 4.62 & 4.60 & 4.80 & 4.77 & 5.08 & 5.30 & 114 \\
\hline Poland & 4.24 & 4.36 & 4.10 & 4.50 & 4.61 & 4.94 & 5.50 & 130 \\
\hline $\begin{array}{l}\text { Slovak } \\
\text { Republic }\end{array}$ & 4.66 & 4.38 & 4.30 & 4.20 & 4.43 & 4.51 & 5.00 & 107 \\
\hline Romania & 4.19 & 4.10 & 4.00 & 4.50 & 4.41 & 4.89 & 4.70 & 112 \\
\hline Moldova & 4.62 & 4.83 & 5.30 & 4.80 & 4.84 & 4.80 & 5.40 & 117 \\
\hline Serbia & 4.16 & 4.40 & 4.30 & 4.00 & 3.77 & 4.56 & 4.80 & 115 \\
\hline $\begin{array}{l}\text { North } \\
\text { Macedonia }\end{array}$ & 4.55 & 4.59 & 4.80 & 4.80 & 4.79 & 4.55 & 5.20 & 114 \\
\hline Albania & 4.31 & 4.33 & 4.40 & 4.30 & 4.60 & 4.387 & 4.70 & 109 \\
\hline $\begin{array}{l}\text { Bosnia and } \\
\text { Herzegovina }\end{array}$ & 4.14 & 4.13 & 4.20 & 4.20 & 4.06 & & 4.30 & 104 \\
\hline Montenegro & 4.16 & 3.40 & 4.20 & 4.80 & 4.61 & 4.48 & 4.80 & 115 \\
\hline
\end{tabular}

Source: Authors' systematization and presentation based on the data from the WEF's Travel \& Tourism competitiveness Reports.

In the framework of Price competitiveness pillar, constituent components values were observed. For all analyzed countries, the values of the pillar Price competitiveness ranged from 3.87 to 5.5 in the period from 2007 to 2017 (Table 1). Slovenia was the lowest price competitive in 2007, while other countries had the values of indicator over 4 and thus occupied approximate ranking positions on the world list. In contrast to Slovenia, Slovak Republic recorded high value which indicates that its tourist competitiveness was mainly based on price factors. In the next years, the value of pillar Price competitiveness for all countries was characterized by variable movement, i.e. slight growth and decrease in values depending on the country and the time period. According to the latest report, Poland is the most price competitive, with a score of 5.5, which shows that it is seeking to attract tourists based on lower prices as the most important factor for tourism. Then follow Moldova and Bulgaria. The highest prices of the observed components in 2017 were recorded in Bosnia and Herzegovina, which makes this country, if judged by price factors, as low price competitive in tourism. At the same time, during the observed period, this country also recorded the smallest increase in the value of pillar Price competitiveness. Poland has made the biggest step forward in terms of price competitiveness in tourism in 2017 compared to 2007. As the overall country competitiveness depends on price and non-price factors, and having in mind the evidence of the price sensitivity of travel demand, countries should strive to achieve price differentiation compared to the other and thus achieve better visibility and attractiveness for tourists.

By using the statistical technique for investigating the relationship between variables, correlations, the relationship between pillar price competitiveness and its components (Ticket taxes and airport charges, Purchasing power parity, Hotel price index, Fuel price levels) for the observed groups of countries in 2015 and 2017 was investigated (Table 2). 
Table 2. Correlation between Price competitiveness pillar and its components for EECs

\begin{tabular}{|c|c|c|c|c|c|}
\hline \multicolumn{6}{|c|}{ Correlations } \\
\hline & & EE_tt15 & EE_hp15 & EE_ppp15 & EE_fp15 \\
\hline \multirow{4}{*}{ EE_pc15 } & Pearson Correlation & 542 &,- 527 &,$- 868^{*}$ &,--571 \\
\hline & Sig. (2-tailed) & ,209 & 283 & 011 &, 181 \\
\hline & $\mathrm{N}$ & 7 & 6 & 7 & 7 \\
\hline & & EE_tt17 & EE_hp17 & EE_ppp17 & EE_fp17 \\
\hline \multirow{3}{*}{ EE_pc17 } & Pearson Correlation &, $855^{*}$ &,$- 864 *$ &,- 464 &,$- 849^{*}$ \\
\hline & Sig. (2-tailed) & ,014 & 026 & 294 & 016 \\
\hline & $\mathrm{N}$ & 7 & 6 & 7 & 7 \\
\hline
\end{tabular}

Source: Prepared by the authors (SPSS 22.0).

By calculating the Pearson coefficient for pillar Price competitiveness and its components in 2015 for the EECs, it can be concluded that there is a medium to strong correlation between them. The negative correlation exists between Price competitiveness and Hotel price index, Price competitiveness and Purchasing power parity, as well as Price competitiveness and Fuel price levels, while there is the positive correlation between Price competitiveness and Ticket taxes. The correlation between these variables in 2017 is predominantly negative with a strong intensity. In addition, the correlation coefficient is statistically significant for the most observed variables. The value of the correlation coefficient is above 0.8 except for the Purchasing power parity component.

Table 3. Correlation between Price competitiveness pillar and its components for WBCs

\begin{tabular}{|c|c|c|c|c|c|}
\hline \multicolumn{6}{|c|}{ Correlations } \\
\hline & & WB_tt15 & WB_hp15 & WB_ppp15 & WB_fp15 \\
\hline \multirow{3}{*}{ WB_pc15 } & Pearson Correlation &, 404 & a &, 383 &,- 711 \\
\hline & Sig. (2-tailed) & ,596 & . & 617 & 289 \\
\hline & $\mathrm{N}$ & 4 & 1 & 4 & 4 \\
\hline & & WB_tt17 & WB_hp17 & WB_ppp17 & WB_fp17 \\
\hline \multirow{3}{*}{ WB_pc17 } & Pearson Correlation &, 842 &. $\mathrm{a}$ &,- 766 & $-\overline{571}$ \\
\hline & Sig. (2-tailed) & 073 & &, 131 & ,315 \\
\hline & $\mathrm{N}$ & 5 & 1 & 5 & 5 \\
\hline
\end{tabular}

Source: Prepared by the authors (SPSS 22.0).

Medium strong to strong correlation between Price competitiveness and its components in 2015 and 2017 is characterized for the WBCs (Table 3). The strongest direct link exists between Price competitiveness and Ticket taxes in 2017 (0.842), while the weakest direct intensity is observed between Price competitiveness and Purchasing power parity in 2015 (0.383). Based on the results of the correlation analysis given in Table 3, there is negative quantitative agreement between Price competitiveness and Fuel price levels in both observed years. In contrast, positive quantitative agreement is expressed in relation to Price competitiveness and Ticket taxes for both years.

The impact of the components values on the total value of the Price competitiveness was examined by applying the multiple regression analysis. Taking into account methodological changes, the analysis covers the last two years (2015 and 2017). Also, the selected group of countries is divided into the WBCs and EECs. For the analysed years, the values of determination coefficient indicate that the models are statistically representative $(0.88-1)$. Multiple regression models 
for both groups show that the unit increase in Ticket taxes affects the increase in the value of the Price competitiveness in the interval from 0.23 to 0.61 , depending on the observed year. The unit increase in the components Hotel price index, Purchasing power parity and Fuel price levels, cause decrease in Price competitiveness for 0.3, considering the EECs. In the WBCs, the opposite trends have been recorded in 2015 compared to 2017. More specifically, the Purchasing Power Parity component leads to an increase in the value of Price competitiveness by about 0.5 in 2015, while reducing the value of Price competitiveness for the same amount in 2017. The Fuel Price component has reacted in a similar way.

In order to classify European countries into homogeneous groups based on pillar Price competitiveness in 2017, we have chosen hierarchical (agglomerative) grouping according to Ward method (method of variance). As a measure of similarity/distance between countries, the Euclidean distance is used (Euclidean distance, square root of the sum of squared differences in values of Price competitiveness). Decision on the number of clusters relies on meaningfulness, as the main criterion in the analysis. According to the values of Price competitiveness, classification is performed in two clusters.

Table 4. Schedule of selected European countries by clusters according to the value of pillar price competitiveness (2017)

\begin{tabular}{|c|c|c|c|c|l|}
\hline Cluster & $\mathrm{N}$ & Mean & Minimum & Maximum & Country \\
\hline 1 & 8 & 4,70 & 4,30 & 5,00 & $\begin{array}{l}\text { Hungary, Slovenia, Serbia, Albania, Bosnia and } \\
\text { Herzegovina, Montenegro, Slovakia, Romania }\end{array}$ \\
\hline 2 & 4 & 5,35 & 5,20 & 5,50 & Bulgaria, North Macedonia, Poland, Moldova \\
\hline Total & 12 & 4,92 & 4,30 & 5,50 & \\
\hline
\end{tabular}

Source: Prepared by the authors (SPSS 22.0).

The Table 4 shows the classification of selected European countries by clusters. According to the values of Price competitiveness, it can be noted that the first cluster is more numerous and contains countries whose tourism competitiveness is mainly based on non-price factors. The second cluster consists of four countries which have higher value of pillar Price competitiveness. Hence, it indicates that Bulgaria, North Macedonia, Poland and Moldova are trying to achieve tourism competitiveness on the basis of price components. The countries in the second cluster are more competitive and therefore more attractive and suitable. For the further interpretation of clusters, the statistical technique ANOVA was used to check the statistical significance of the differences between the average values of variable between the clusters. Statistically significant differences between the group average values for the observed variable were determined by the homogeneity test of the variance. The results of the Levene test for equality of variances has verified the homogeneity of the variance of the groups and since significance is greater than 0.05 and amount to 0.757 , it can be stated that the condition for the implementation of the ANOVA technique is confirmed.

Table 5. Results of ANOVA procedure for variable price competitiveness

\begin{tabular}{|l|c|c|c|c|c|}
\hline \multicolumn{7}{|c|}{ ANOVA } \\
\hline pc2017 & Sum of Squares & df & Mean Square & F & Sig. \\
\hline & 1,127 & 1 & 1,127 & 34,141 &, 000 \\
\hline Between Groups &, 330 & 10 &, 033 & & \\
\hline Within Groups & 1,457 & 11 & & & \\
\hline Total & S & & & \\
\hline
\end{tabular}

Source: Prepared by the authors (SPSS 22.0). 
Based on the value of $\mathrm{F}$ test and its significance (Sig.) which is less than 0.05 , there are statistically significant differences between groups (Table 5). The observed difference suggests that different countries' pretensions for improvement tourism competitiveness are based on (non) price factors. According to conducted empirical research, price components are important for improving the tourism competitiveness, but they are not the only influential factor on general tourism competitiveness, but also non-price factors should be considered which are not taken into account in this paper.

In the following analysis, forecasting of the price competitiveness values for 2018 and 2020 was performed for both groups of countries. Prediction of future price competitiveness values was done according to the average values in the period 2007-2017.

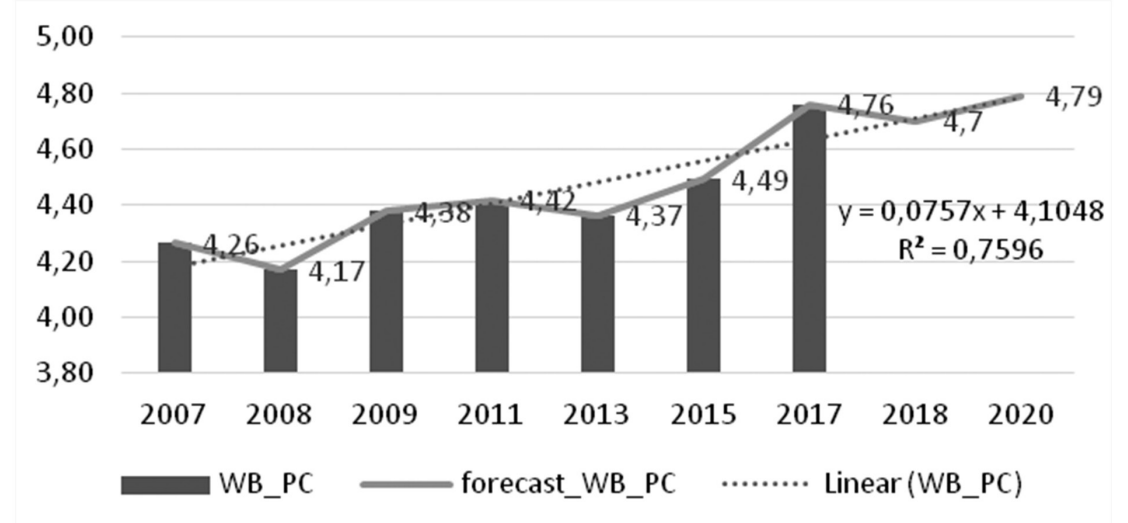

Figure 2. Real and projected values of the pillar Price competitiveness for the WBCs (2007-2020)

Source: Authors' presentation and calculation based on the data from the WEF's Travel \& Tourism competitiveness Reports.

The oscillatory trend of the price competitiveness with a pronounced peak in 2017 is characterized for the WBCs. The projected values of the price competitiveness component will continue to oscillate around the value of 4.7. The expected value of this indicator for 2020 is 4.79. This indicates that the WBCs will, on average, be more price competitive in the upcoming period given the increase in values over time.

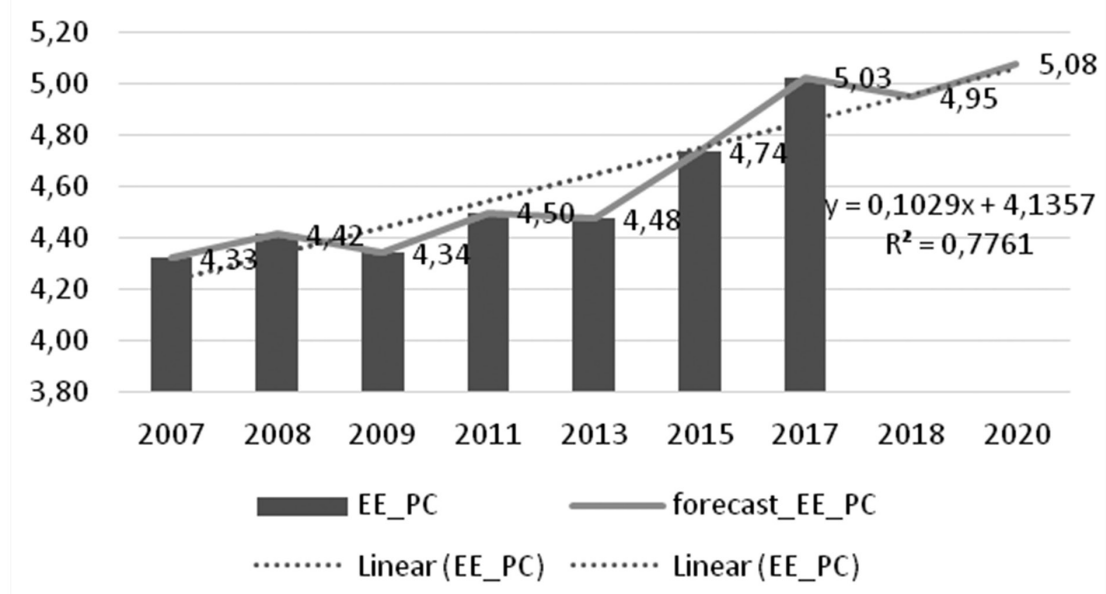

Figure 3. Real and projected values of the pillar Price competitiveness for EECs (2007-2020)

Source: Authors' presentation and calculation based on the data from the WEF's Travel \& Tourism competitiveness Reports. 
On the other hand, the obtained results suggest that the EECs are, on average, more price competitive compared to the WBCs, given the higher value of the selected indicator. The projected values for price competitiveness for the period up to 2020 indicate a less pronounced increase in price competitiveness in 2020 compared to level that was achieved in 2017 compared to the previous year.

\section{FUTURE RESEARCH DIRECTIONS}

The future research directions will be the relationship between tourism price competitiveness and tourist arrivals and tourism receipts, due to the price of goods and services represents an important factor of attracting tourists and improving destination competitiveness. The empirical research will test the following hypothesis: whether lower prices in tourism contribute to a greater number of tourist arrivals and higher tourism receipts.

\section{CONCLUSION}

The paper examines the impact of price competitiveness on the overall tourism competitiveness in the EECs (Hungary, Slovenia, Poland, Moldova, Bulgaria, Slovakia, and Romania) and WBCs (Serbia, Montenegro, Bosnia and Herzegovina, North Macedonia, and Albania) in the period from 2007 to 2017. The results of the conducted TTCI analysis for the selected countries indicate that in the period from 2009 to 2017, there was a significant decline in the rank for WBCs, stating that similar trend is registered in the EECs. The most pronounced drop in TTCI, among WBCs, recorded in Montenegro (followed by a decline from the 36th position in 2011 to 72th in 2017), while among the EECs, this decrease is evident in the case of the Slovak Republic (decrease from 37th place in 2007 to 59th place in 2017). In addition, it was found that the value of pillar Price competitiveness in the period from 2007 to 2017 ranged from 3.87 to 5.5 in both groups of countries. According to this indicator, Poland is the leader among all the observed countries, since it is the most price competitive according to the latest report, while the lowest increase in the value of pillar price competitiveness recorded in Bosnia and Herzegovina.

The results of the correlation analysis, which was applied for determining the link between pillar Price competitiveness and its components do not fully, confirmed the first hypothesis. Namely, it has been found that there is a medium strong to strong correlation between the variables for 2015 and 2017 for the EECs and the WBCs, and a positive link is present between pillar price competitiveness and Ticket Taxes.

In order to examine the influence of the pillar price competitiveness components, on its total value, multiple regression analysis was applied. It has been confirmed for both groups of countries, that the unit increase in Ticket taxes affects the increase in the value of price competitiveness pillar in the range of 0.23 to 0.61 , depending on the observed year. In the EECs, the unit increase in the Hotel price index, Purchasing power parity and Fuel price levels causes a decline in the value of price competitiveness pillar by about 0.3 . In the case of the WBCs, component Purchasing power parity leads to an increase value of pillar for 0.5 in 2015, while in 2017 it reduces the value of pillar for the same amount. Similar behaviour was recorded for the component Fuel price levels.

The results of cluster analysis suggest that Bulgaria, North Macedonia, Poland and Moldova are in the second smaller cluster, which consists of countries that based their tourism com- 
petitiveness primarily on price factors. This statement was further confirmed by the results of the ANOVA procedure for variable price competitiveness: there are statistically significant differences between groups regarding the importance of price factors for improving tourism competitiveness.

The results of this research provide the relevant theoretical and practical evidence about the impact of price factors on tourism competitiveness. The paper present good basis for concluding that the WBCs are not more price competitive than the EECs, which rejects the second hypothesis. Namely, throughout the observed period (2007-2017), the values of pillar Price competitiveness for the WBCs are lower compared to the EECs, although the projection of price competitiveness values for 2018 and 2020 suggest that it will continue the upward trend. In addition, the projected future values of Price competitiveness pillar for the EECs fully confirm the third hypothesis: these countries will continue to build tourism competitiveness on price factors in the coming period.

Given that the price represents one of the main determinants of tourism demand, this paper carries one important recommendation to the economic policy makers in the EECs, and particularly in the WBCs. They should pay more attention to price factors in the following period in order to improve the price competitiveness of countries, as one of the important strategies for improving the level of tourism competitiveness.

\section{ACKNOWLEDGMENT}

This research was supported by the Ministry of Education, Science and Technology of the Republic of Serbia [grant numbers 44007 and 179066].

\section{REFERENCES}

Athanasopoulos, G., Deng, M., Li, G., \& Song, H. (2014). Modelling substitution between domestic and outbound tourism in Australia: a system-of-equations approach. Tourism Management, 45: 159-170.

Cortez-Jimenez, I., Durbarry, R., \& Pulina, M. (2009). Estimation of outbound Italian tourism demand: a monthly dynamic EC-LAIDS model. Tourism Economics, 15(3): 547-565.

Croes, R. (2010). Measuring and explaining competitiveness in the context of small island destinations. Journal of Travel Research, 50(4): 431-442.

Crouch, G. I. (2011). Destination competitiveness: an analysis of determinant attributes. Journal of Travel Research, 50(1): 27-45.

Divisekera, S., \& Kulendran, N. (2006). Economic effects of advertising on tourism demand: a case study. Tourism Economics, 12(2): 187-205.

Dwyer, L., \& Forsyth, P. (2011). Methods of estimating destination price competitiveness: a case of horses for courses? Current Issues in Tourism, 14(8): 751-777.

Dwyer, L., Forsyth, P., \& Rao, P. (2000). The price competitiveness of travel and tourism: a comparison of 19 destinations. Tourism Management, 21(1): 9-22.

Dwyer, L., Forsyth, P., \& Rao, P. (2002). Destination price competitiveness: exchange rate changes versus domestic inflation. Journal of Travel Research, 40(3): 328-336.

Enright, M. J., \& Newton, J. (2004). Tourism destination competitiveness: a quantitative approach. Tourism Management, 25(6): 777-788.

Etzo, I., Massidda, C., \& Piras, R. (2014). Migration and outbound tourism: evidence from Italy. Annals of Tourism Research, 48: 235-249. 
Forsyth, P., \& Dwyer, L. (2009). Tourism price competitiveness. In J. Blanke \& T. Chiesa (Eds.), The Travel \& Tourism Competitiveness Report - Managing in a Time of Turbulence (pp. 77-90). Geneva: World Economic Forum.

Frechtling, D. C. (2001). Forecasting Tourism Demand: Methods and Strategies. Oxford, UK: Butterworth Heinemann.

Galovski, D. (2018). Comparison and the effectiveness of tourism policies between Macedonia and Serbia. Turizam, 22(2), 42-51.

Gooroochurn, N., \& Sugiyarto, G. (2005). Competitiveness indicators in the travel and tourism industry. Tourism Economics, 11(1): 25-43.

Halicioglu, F. (2010). An econometric analysis of the aggregate outbound tourism demand of Turkey. Tourism Economics, 16(1): 83-97.

Harrison, D. (2001). Less developed countries and tourism: the overall pattern. In D. Harrison (Ed.), Tourism and the less Developed World: Issues and Case Studies (pp. 1-22). Wallingford: CAB International.

Ivanov, S., \& Webster, C. (2013). Globalization as a driver of destination competitiveness. Annals of Tourism Research, 43: 628-633.

Kayar, C. H., \& Kozak, N. (2007). Measuring destination competitiveness: an application of the travel and tourism competitiveness index. Journal of Hospitality Marketing and Management, 19(3): 203-216.

Kester, J., \& Croce, V. (2011). Tourism development in advanced and emerging economies: what does the travel \& tourism competitiveness index tell us? In J. Blanke \& T. Chiesa (Eds.), The Travel \& Tourism Competitiveness Report - Beyond The Downturn (pp. 45-52). Geneva: World Economic Forum.

Krstic, B., Jovanovic, S., Jankovic-Milic, V., \& Stanisic, T. (2016). Examination of travel and tourism competitiveness contribution to national economy competitiveness of sub-Saharan Africa countries. Development Southern Africa, 33(4): 470-485.

Li, G., Song, H., \& Witt, S. F. (2004). Modelling tourism demand: a dynamic linear AIDS approach. Journal of Travel Research, 43: 141-150.

Li, G., Song, H., \& Witt, S. F. (2005). Recent developments in econometric modeling and forecasting. Journal of Travel Research, 44: 82-99.

Lim, C. (2006). A survey of tourism demand modelling practice: Issues and implications. In L. Dwyer \& P. Forsyth (Eds.), International Handbook on the Economics of Tourism (pp. 4572). Cheltenham, UK: Edward Elgar Publishing.

Lipsey, R. G. (2009). An Introduction to Positive Economics (7th ed.). Oxford: Oxford University Press.

Mangion, M., Durbarry, R., \& Sinclair, M. T. (2005). Tourism competitiveness: price and quality. Tourism Economics, 11(1): 45-68.

Mowforth, M., \& Munt, I. (2009). Tourism and Sustainability: Development, Globalisation and New Tourism in the Third World (3rd ed.). London: Routledge.

Muchapondwa, E., \& Pimhidzai, O. (2011). Modelling international tourism demand for Zimbabwe. International Journal of Business and Social Science, 2(2): 71-81.

Petrović, J., Milićević, S., \& Djeri, L. (2017). The information and communications technology as a factor of destination competitiveness in transition countries in European Union. Tourism Economics, 23(6): 1353-1361.

Plessis, E., \& Saayman, M. (2018). Aspects contributing to tourism price competitiveness of South Africa. Tourism Economics, 24(2): 146-156.

Ritchie, J. R. B., \& Crouch, G. I. (2003). The Competitive Destination: A Sustainable Tourism Perspective. Wallingford: CABI Publishing. 
Seo, J. H., Park, S. Y., \& Yu, L. (2009). The analysis of the relationships of Korean outbound tourism demand: Jeju Island and three international destinations. Tourism Management, 30(4): 530-543.

Sharpley, R., \& Telfer, D. J. (2008). Tourism and Development in the Developing World. London: Routledge.

Song, H., \& Li, G. (2008). Tourism demand modelling and forecasting - a review of recent research. Tourism Management, 29(2): 203-220.

Song, H., \& Turner, L. (2006). Tourism demand forecasting. In L. Dwyer \& P. Forsyth (Eds.), International Handbook on the Economics of Tourism (pp. 89-114). Cheltenham: Edward Elgar.

Song, H., \& Witt, S. F. (2000). Tourism Demand Modelling and Forecasting: Modern Econometrics Approaches. Cambridge, UK: Pergamon.

WEF (2007). The Travel and Tourism Competitiveness Report: Furthering the Process of Economic Development. Geneva: World Economic Forum. Available at: http://citeseerx.ist. psu.edu/viewdoc/download?doi=10.1.1.178.3367\&rep=rep1\&type=pdf (accessed 15 January 2018).

WEF (2008). The Travel and Tourism Competitiveness Report: Balancing Economic Development and Environmental Sustainability. Geneva: World Economic Forum. Available at: https://www.ub.unibas.ch/digi/a125/sachdok/2014/BAU_1_6306075.pdf (accessed 15 January 2018).

WEF (2009). The Travel and Tourism Competitiveness Report: Managing in a Time of Turbulence. Geneva: World Economic Forum. Available at: http://www.ontit.it/opencms/export/sites/default/ont/it/documenti/files/ONT_2009-03-04_02101.pdf (accessed 15 January 2018).

WEF (2011). The Travel and Tourism Competitiveness Report: Beyond the Downturn. Geneva: World Economic Forum. Available at: http://www3.weforum.org/docs/TTCR11/ (accessed 15 January 2018).

WEF (2013). The Travel and Tourism Competitiveness Report: Reducing Barriers to Economic Growth and Job Creation. Geneva: World Economic Forum. Available at: http://www3. weforum.org/docs/WEF_TT_Competitiveness_Report_2013.pdf (accessed 15 January 2018).

WEF (2015). Travel \& Tourism Competitiveness Report - Growing through Shocks. Available at: http://www3.weforum.org/docs/TT15/WEF_Global_Travel\&Tourism_Report_2015.pdf (accessed 15 January 2018).

WEF (2017). The Travel and Tourism Competitiveness Report - Paving the way for a more sustainable and inclusive future. Geneva: World Economic Forum. Available at: http://www3. weforum.org/docs/WEF_TTCR_2017_web_0401.pdf (accessed 15 January 2018). 